\title{
Penerapan Sistem Penilaian Kinerja Berbasis E-Kinerja Terhadap Prestasi Kerja Pegawai Melalui Kepuasan Kerja Sebagai Variabel Intervening Pada Dinas Kependudukan dan Pencatatan Sipil Kabupaten Banyuwangi
}

\author{
(Implementation of Performance Appraisal System Based on E-Performance on Employee \\ Achievement Through Job Satisfaction as An Intervening Variable on Dinas \\ Kependudukan dan Pencatatan Sipil Kabupaten Banyuwangi)
}

\author{
Dwi Rafita Mukti*, Sri Wahyu Lelly Hana Setyanti, Lilik Farida \\ Jurusan Manajemen, Fakultas Ekonomi dan Bisnis, Universitas Jember (UNEJ) \\ Jln. Kalimantan 37, Jember 68121 \\ E-mail: dwi.rafita01@gmail.com
}

\begin{abstract}
Abstrak
Penelitian ini bertujuan untuk mengetahui pengaruh penilaian kinerja berbasi e-kinerja terhadap prestasi kerja pegawai melalui kepuasan kerja sebagai variabel intervening pada Dinas Kependudukan dan Pencatatan Sipil Kabupaten Banyuwangi. Jenis penelitian adalah jenis studi kausal yaitu tipe penelitian karakteristik masalah berupa hubungan sebab-akibat antara dua variabel atau lebih. Populasi penelitian adalah pegawai pada Dinas Kependudukan dan Pencatatan Sipil Kabupaten Banyuwangi yang sebanyak 80 orang. Metode pengambilan sampel dalam penelitian ini dilakukan dengan teknik purposive sampling dan diperoleh 37 responden sebagai sampel. Metode analisis data yang digunakan adalah analisis jalur/path. Hipotesis pada penelitian ini antara lain penilaian kinerja berbasis e-kinerja berpengaruh signifikan terhadap prestasi kerja, penilaian kinerja berbasis e-kinerja berpengaruh signifikan terhadap kepuasan kerja, dan kepuasan kerja berpengaruh signifikan terhadap prestasi kerja. Hasil penelitian ini adalah penilaian kinerja berbasis e-kinerja berpengaruh positif dan signifikan terhadap prestasi kerja pegawai. Artinya penilaian kinerja berbasis e-kinerja dapat meningkatkan prestasi kerja pegawai. Peniaian Kinerja berbasis e-kinerja berpengaruh positif dan signifikan terhadap kepuasan kerja pegawai. Artinya penilaian kinerja berbasis e-kinerja dapat meningkatkan kepuasan kerja pegawai. Kepuasan Kerja memiliki pengaruh positif dan signifikan terhadap Prestasi kerja pegawai. Artinya keberhasilan pegawai dalam melaksanakan tugas yang diberikan oleh organisasi mampu meningkatkan kepuasan kerja yang didapatkan.
\end{abstract}

Kata Kunci: Penilaian Kinerja, E-Kinerja, Kepuasan Kerja, Prestasi Kerja.

\begin{abstract}
This study aims to knowing the influence of performance appraisal system based on e-performance on employee achievement through job satisfaction as an intervening variable on Dinas Kependudukan dan Pencatatan Sipil Kabupaten Banyuwangi. This study is causal research, it means problem characteristics research in a form cause-effect between two variables or more. Population is employees of Dinas Kependudukan dan Pencatatatn Sipil Kabupaten Banyuwangi with the amount 80 employees. The sampling method for this study was doing with purposive sampling technique and it has been gotten 37 respondents as samples. Data analysis method is Path Analysis. The hypothesis of research are performance appraisal based on e-performance has significantly affected job achievement, performance appraisal based on e-performance has significantly affected job satisfaction, and job satisfaction has significantly affected job achievement. The result of study was performance appraisal based on e-performance has positive and significantly affected employees achevement. It means performance appraisal based on e-performance can increase employee achievement. Performance appraisal based on e-performance has positive and significantly affected job satisfaction on employees. It means performance appraisal based on e-performance can increase job satisfaction on employees. Job satisfaction has positive and significantly affected employees achievement. It means the employees successfully in doing the tasks which have been given by company can increase job satisfaction which got.
\end{abstract}

Keywords: Performance Appraisal, E-Performance, Job Saticfaction, employee acievement.

\section{Pendahuluan}

Kabupaten Banyuwangi mengalami peningkatan perekonomian yang begitu pesat selama enam tahun terakhir. Peningkatan perekonomian dilakukan dari berbagai sektor

seperti pertanian, parawisata, serta usaha mikro, kecil dan menengah (UMKM) sebagai preoritas utama yang diperhatikan oleh Pemerintah Kabupaten Banyuwangi dalam membantu peningkatan perekonomian masyarakat.
Berdasarkan laporan kinerja Kabupaten Banyuwangi Tahun 2015, dalam upaya penyelenggaraan pemerintahan, Kabupaten Banyuwagi menyelenggarakan dengan prinsip pada pemerintahan yang baik dan berorientasi pada hasil. Untuk mencapai hal tersebut perlu adanya perbaikan pada sumber daya manusia yang menjadi faktor terpenting dalam organisasi pemerintahan. Perbaikan yang menjadi perhatian pemerintah Kabupaten Banyuwangi adalah kinerja Pegawai Negri Sipil (PNS) yang dinilai masih kurang memenuhi standar. Pemerintah Kabupaten Banyuwangi mulai Januari

* Corresponding author 
2017 menerapkan sistem e-kinerja yang berguna untuk mengukur kinerja seluruh pegawai negri sispil yang bertujuan untuk meningkatkan kinerja aparatur pemerintahan, dengan memberikan tambahan jumlah tunjangan yang didapat dari hasil kerja yang dilakukan. Salah satu upaya dalam menjalankan prinsip tersebut pemerintah Kabupeten Banyuwangi menerapkan sistem e-kinerja pada seluruh pegawai negri sipil (banyuwangikab.go.id).

Penilaian kinerja berbasis e-kinerja merupakan terobosan baru pemerintah Kabupaten Banyuwangi dalam rangka meningkatkan kinerja PNS dengan pemberian tunjangan yang berbeda setiap bulannya berdasarkan hasil kerja yang mampu dicapai. Dengan adanya sistem penilaian kinerja ini, diharapkan pekerjaan yang dilakukan lebih produktif dari sebelumnya. Sehingga pemberian tunjangan sesuai dengan tingkat pekerjaan yang dilakukan oleh pegawai. Semakin produktif kinerja yang dilakukan semakin besar pula tunjangan yang didapat begitupun sebaliknya apabila kinerja menurun maka mereka akan mendapat imbalan sesuai dengan hasil kerja. Nilai capaian aktivitas kerja pegawai berdasarkan waktu yang telah ditetapkan e-kinerja, dengan pemberlakuan jam maksimal dan minimal untuk memberikan tunjangan penghasilan kepada pegawai bersatus PNS.

E-kinerja merupakan aplikasi yang dibuat khusus untuk menilai kinerja pegawai secara langsung dengan memasukkan data kerja harian kedalam software, untuk mendapat persetujuan dari atasan. Setelah persetujuan didapat, maka output dari hasil kerja yang dilakukan secara online, secara otomatis data yang dihasilkan akan terlihat. Data tersebut berupa jumlah nominal dari tarif tunjangan yang diterima pegawai. Dukungan sumber daya manusia yang memiliki kinerja tinggi, dibantu dengan melakukan perbaikan sistem, meningkatkan tunjangan, memberikan informasi serta pelayanan yang baik, meningkatkan efektifitas serta efisiensi sesuai dengan prosedur yang ditetapkan atau standar oprasional prosedur yang diberikan maka kinerja akan meningkat. Munculnya inovasi-inovasi terbaru di bidang pelayanan publik yang diciptakan guna memberi kesejahteraan masyarakat.

Organisasi pemerintah di bidang pelayanan publik merupakan industri jasa yang memerlukan kontak langsung dengan masyarakat. Pertumbuhan penduduk yang bergerak begitu cepat dari tahun ke tahun merupakan tantangan bagi Dispendukcapil Kabupaten Banyuwangi untuk tetap konsisten dalam memberikan pelayanan yang terbaik kepada masyarakat. Hal tersebut perlu dukungan dari dalam organisasi untuk membentuk sumber daya manusia yang memiliki kinerja tinggi didukung dengan penerapan penilaian kinerja kepada pegawai negri sipil. Inovasi pada sistem penilaian kinerja yang lebih transparan dengan diberlakukannya e-kinerja merupakan salah satu faktor yang mendorong agar pegawai yang berstatus sebagai PNS untuk lebih kreatif dan inovatif. Penilaian kinerja yang dilakukan tersebut bertujuan untuk meningkatkan kepuasan serta prestasi kerja yang dapat dicapai secara riil oleh pegawai.

Penilaian kinerja adalah salah satu metode yang dapat digunakan oleh perusahaan atau organisasi untuk mengetahui dan menilai seberapa besar kepuasan kerja karyawan terhadap pekerjaan yang dilakukan serta lingkungan kerja yang ditempati (Cindi, 2015). Pembaharuan sistem dalam mengukur kinerja PNS dengan diterapkannya e-kinerja dapat meningkatkan kepuasan kerja pegawai dengan perolehan tunjangan yang sesuai dengan harapan. Kepuasan kerja pegawai menjadi salah satu preoritas yang perlu difikirkan dalam organisasi, karena penilaian kinerja dan kepuasan kerja menjadi pendorong peningkatan prestasi kerja. Penilaian kinerja yang dilakukan dapat mempengaruhi kepuasan kerja pegawai. Menurut Susilo (2006:142) kepuasan kerja adalah keadaan emosional karyawan dimana terjadi ataupun tidak terjadi titik temu antara nilai balas jasa karyawan dari perusahaan dengan tingkat nilai balas jasa yang memang diinginkan karyawan yang bersangkutan. Kepuasan kerja menjadi salah satu faktor pendorong pencapaian prestasi kerja pegawai. Menurut Malayu Hasibuan (2008:94), pestasi kerja adalah suatu hasil kerja yang dicapai seseorang dalam melaksanakan tugas-tugas yang dibebankan kepada yang didasarkan kecakapan, pengalaman dan kesungguhan serta waktu. Kepuasan kerja yang diperoleh, diharapkan akan meningkatkan kinerja yang lebih tinggi. Sehingga dapat diketahui bahwa tidak hanya berdasarkan kemampuan yang diperlukan dalam mencapai prestasi kerja.

Peningkatan jumlah penduduk yang begitu cepat, dapat menjadi masalah bagi organisasi pemerintah apabila hal tersebut tidak segera ditangani dengan tertib dan terstruktur dengan baik. Dukungan dari pemerintah pusat maupun pemerintah daerah untuk menciptakan pelayanan publik yang tertib administrasi, bersih dan transparan menjadi acuan bagi Dinas Kependudukan dan Pencatatan Sipil Kabupaten Banyuwangi untuk melakukan pembaharuan yang lebih modern dengan sistem yang tersusun dengan baik dalam memberikan kemudahan pelayanan kepada masyarakat.

Capaian besar yang diperoleh Dispenduk Kabupaten Banyuwangi dengan peningkatan prestasi dalam bidang pelayanan publik, tidak lepas dari pengaruh sumber daya manusia dan sistem organisasi yang baik. Dinas Kependudukan dan Pencatatan Sipil Kabupaten Banyuwangi melakukan inovasi di bidang pelayanan publik dengan menerapkan sistem layanan "Lahir Procot Pulang Bawa Akta (LPPBA)". LPPBA merupakan tindak lanjut Peraturan Bupati Banyuwangi Nomor 42 Tahun 2013 tentang pelayanan pengurusan akta kelahiran secara online di Kabupaten Banyuwangi. Sistem LPPBA ditetapkan pada tanggal 14 Nopember 2013 di Puskesamas Gitik, Kecamatan Rogojampi (jipp.jatimprov.go.id). Untuk itu diharapkan dengan adanya penilaian kinerja berbasis e-kinerja akan dapat lebih memacu seluruh dinas yang berhubungan dengan pelayanan publik dapat memberikan hasil lebih optimal dan dapat meningkatkan prestasi kerja pegawai negeri sipil.

Berdasarkan uraian tersebut, hipotesis dalam penelitian ini antara lain penilaian kinerja berbasis e-kinerja berpengaruh signifikan terhadap prestasi kerja, penilaian kinerja berbasis e-kinerja berpengaruh signifikan terhadap kepuasan kerja, dan kepuasan kerja berpengaruh signifikan terhadap prestasi kerja.

Adapaun rumusan masalah pada penelitian ini adalah (1) apakah terdapat pengaruh penilaian kinerja berbasis e-kinerja terhadap kepuasan kerja pegawai Dinas Kependudukan dan Pencatatan Sipil Kabupaten Banyuwangi? (2) Apakah terdapat pengaruh penilaian kinerja berbasis e-kinerja terhadap prestasi kerja pegawai Dinas Kependudukan dan Pencatatan Sipil Kabupaten Banyuwangi? (3) Apakah terdapat pengaruh kepuasan kerja terhadap prestasi kerja 
pegawai Dinas Kependudukan dan Pencatatan Sipil Kabupaten Banyuwangi?

Tujuan dari penelitian ini adalah mengetahui pengaruh penilaian kinerja berbasi e-kinerja terhadap prestasi kerja pegawai melalui kepuasan kerja sebagai variabel intervening pada Dinas Kependudukan dan Pencatatan Sipil Kabupaten Banyuwangi.

\section{Metode}

\section{Rancangan Penelitian}

Jenis penelitian ini adalah penelitian jenis studi kausal yaitu tipe penelitian karakteristik masalah berupa hubungan sebabakibat antara dua variabel atau lebih.

\section{Jenis dan Sumber Data}

Jenis data yang digunakan dalam penelitian ini adalah data kuantitatif. Sumber data yang digunakan dalam penelitian ini meliputi data primer dan data skunder. Data primer dalam penelitian ini diperoleh dari responden dengan memberikan kuosioner kepada pegawai yang berisi tentang pernyataan yang diteliti, tentang penilaian E-kinerja, kepuasan kerja dan prestasi kerja pegawai Dinas Kependudukan dan Pencatatan Sipil Kabupaten Banyuwangi. Data sekunder diperoleh dari buku-buku, jurnal, penelitian terdahulu dan internet yang berkaitan dengan penelitian mengenai sumber teori dan data penilaian e-kinerja, kepuasan kerja serta prestasi kerja.

\section{Populasi dan Sampel}

Populasi pada penelitian ini adalah karyawan yang ada pada Dinas Kependudukan dan Pencatatan Sipil Kabupaten Banyuwangi adalah sebanyak 80 orang. Teknik pengambilan sampel yang digunakan adalah purposive sampling yaitu teknik pengambilan sampel dengan menggunakan kriteria tertentu. Kriteria responden dalam penelitian ini adalah seluruh pegawai Dinas Kependudukan dan Pencatatan Sipil Kabupaten Banyuwangi yang bersetatus sebagai Pegawai Negri Sipil (PNS) sebanyak 37 orang.

\section{Metode Analisis Data}

Penelitian ini menggunakan metode analisis jalur/Path Analysis.

\section{Hasil dan Pembahasan}

\section{Hasil}

\section{Karakteristik Responden}

Dalam penelitian ini untuk memperoleh kajian mengenai penerapan sistem penilaian kinerja berbasis e-kinerja terhadap kepuasan kerja dan prestasi kerja pegawai, peneliti menggunkan kuisioner sebanyak 21 pernyataan. Dari pernyataan tersebut dibagi menjadi 8 pernyataan tentang penilaian kinerja berbasis e-kinerja, 8 pernyataan mengenai kepuasan kerja dan 5 pernyataan tentang prestasi kerja pegawai. Untuk melakukan analisis hasil dari penelitian diperlukan data hasil penelitian dalam bentuk tabulasi. Distribusi frekuensi disusun berdasarkan atribut responden, yaitu Usia, Jenis kelamin, dan Lama bekerja. Berikut ini beberapa data tabel distribusi frekuensi untuk memberikan gambaran data diri responden pada kuesioner penelitian.
Tabel 1. Karakteristik Responden Berdasarkan Usia

\begin{tabular}{ccc}
\hline Usia (Tahun) & Frekuensi & Persentase \% \\
\hline$>40$ & 10 & 27 \\
$41-50$ & 11 & 29.7 \\
$<60$ & 16 & 43.3 \\
\hline Jumlah & 37 & 100 \\
\hline
\end{tabular}

Sumber: data primer diolah, 2017.

Berdasarkan tabel 1 dapat diketahui bahwa pegawai yang berstastus sebagai PNS dengan usia diatas 50 tahun lebih banyak sebebsa $43.3 \%$, dibanding dengan pegawai dengan usia dibawah 50 tahun. Hal ini menunjukkan bahwa, pengalaman kerja yang dimiliki oleh pegawai Dinas Kependudukan dan Pencatatan Sipil Kabupaten Banyuwangi lebih besar.

Tabel 2. Karakteristik Responden Berdasarkan Jenis Kelamin

\begin{tabular}{ccc}
\hline Jenis Kelamin & Frekuensi & Persentase $\%$ \\
\hline Laki-laki & 22 & 59,46 \\
Perempuan & 15 & 40,54 \\
\hline Jumlah & 37 & 100
\end{tabular}

Sumber: data primer diolah, 2017.

Dari hasil tabel 2, menunjukkan bahwa pegawai laki-laki lebih dominan dibanding dengan pegawai perempuan yang memiliki jumlah lebih sedikit. Hal ini dinilai bahwa pegawai laki-laki lebih cakap dan cenderung tidak emosional dalam menghadapi berbagai masalah yang timbul dalam organisasi.

Tabel 3. Karakteristik Responden Berdasarkan Lama Bekerja

\begin{tabular}{ccc}
\hline Lama Bekerja & Frekuensi & Persentase $\%$ \\
\hline $1-5$ & 2 & 5,41 \\
$6-10$ & 2 & 5,41 \\
$11-20$ & 26 & 70,28 \\
$21-30$ & 7 & 18,9 \\
\hline Jumlah & 37 & 100
\end{tabular}

Sumber: data primer diolah, 2017.

Dari tabel 3, dapat diketahui responden yang masa kerjanya 1-5 tahun berjumlah 2 orang atau $5.41 \%$, responden yang masa kerjanya $6-10$ berjumlah 2 orang atau $5.41 \%$, responden yang masa kerjanya berkisar antara 11-20 tahun berjumlah 26 orang atau $70.28 \%$, responden dengan masa kerja 21-30 berjumlah 7 orang atau $18.9 \%$. Berdasarkan data di atas dapat diketahui bahwa jumlah pegawai yang bekerja lebih dari 10 tahun memiliki jumlah lebih besar sehingga pegawai mampu menangani kinerja dengan dukungan dari pengalaman kerja yang dihadapi oleh pegawai dalam organisasi.

\section{Analisis Data}

Analisis Jalur (Path Analysis)

Tabel 4. Hasil Koefisien Pengaruh Langsung

\begin{tabular}{cccccc}
\hline \multicolumn{2}{c}{ Standarized } & \multirow{2}{*}{ Sig } & A & Ket \\
\cline { 1 - 2 } \multicolumn{1}{c}{ Jalur } & Beta & & & \\
\cline { 1 - 2 } $\mathrm{X} \rightarrow \mathrm{Y}$ & 0,577 & & 0,000 & 0,05 & Signifikan \\
$\mathrm{X} \rightarrow \mathrm{Z}$ & 0,626 & 0,002 & 0,05 & Signifikan \\
$\mathrm{Z} \rightarrow \mathrm{Y}$ & 0,368 & & 0,000 & 0,05 & Signifikan \\
\hline
\end{tabular}

Sumber: hasil analisis jalur/path, 2017. 
Berdasarkan hasil tabel 4, menunjukkan bahwa penilaian kinerja berbasis e-kinerja memiliki pengaruh paling kuat terhadap kepuasan kerja pegawai dengan koefisien jalur langsung sebesar 0.626. Kemudian, dilanjutkan dengan pengaruh penilaian kinerja berbasis e-kinerja terhadap prestasi kerja pegawai dengan nilai koefisien jalur langsung sebesar 0.577. Pengaruh paling lemah dari analisis jalur langsung yakni kepuasan kerja terhadap prestasi kerja pegawai dengan koefisien jalur langsung sebesar 0.369 .

\section{Pembahasan}

\section{Pengaruh Penilaian Kinerja Berbasis E-Kinerja Terhadap Prestasi Kerja}

Hasil Penelitian mengenai penilaian kinerja berbasis e-kinerja memiliki pengaruh terhadap prestasi kerja pegawai Dinas Kependudukan dan Pencatatan Sipil Kabupaten Banyuwangi sebesar 0.577 atau $57.7 \%$ dengan nilai signifikansi sebesar 0.000 . Nilai signifikan penilaian kinerja berbasis e-kinerja lebih kecil dari tingkat $\alpha$ sebesar 0.05 . Berdasarkan hasil uji tersebut dapat diketahui bahwa penilaian kinerja berbasis ekinerja memiliki pengaruh signifikan terhadap prestasi kerja pegawai. Hasil penelitian menunjukkan bahwa penilaian kinerja berbasis e-kinerja dapat meningkatkan prestasi kerja pegawai Dinas Kependudukan dan Pencatatan Sipil Kabupaten Banyuwangi, serta menunjukkan bahwa terdapat pengaruh positif dan signifikan. Berdasarkan jumlah responden sebanyak 37 orang, banyak yang memberi skor setuju terhadap indikator umpan balik penilai sebanyak 19 responden atau $51.35 \%$ pada penilaian kinerja berbasis ekinerja. Umpan balik penilai diberikan guna untuk memperbaiki kinerja pegawai yang dirasa masih kurang dengan memberikan saran, teguran bahkan sanksi, serta menunjukkan hasil kerja yang terbaik yang mampu diraih oleh pegawai dengan diperolahnya jumlah tunjangan lebih yang didapat.

Indikator penetapan standar penilaian memberikan jawaban sangat setuju lebih besar dibanding indikator lainnya, dalam hal ini penilaian kinerja berbasis e-kinerja dominan oleh penetapan standar penilaian yang telah ditentukan secara adil didalam organisasi kepada setiap pegawai Dinas Kependudukan dan Pencatatan Sipil Kabupaten Banyuwangi. Indikator presensi serta aktivitas kinerja bulanan merupakan aspek penting dalam mendukung peningkatan kinerja pegawai agar lebih disiplin dan bertanggung jawab dalam menyelesaikan pekerjaan dengan tepat waktu. Kecakapan yang dimiliki oleh pegawai Dispendukcapil mampu mendukung peningkatan prestasi kerja secara individu maupun secara tim, dengan menerapkan kerja sama yang baik antar pegawai baik dengan rekan kerja, atasan maupun dengan bawahan. Hal tersebut merupakan salah satu tolak ukur dalam penerapan penilain kinerja dengan menggunkan basis e-kinerja untuk mencapaian tujuan organisasi yang mampu mendorong peningkatan prestasi kerja pegawai baik didalam maupun luar organisasi.

Paparan analisis tersebut, mendukung penelitian Cindy (2015) dengan hasil penelitian yang menyebutkan bahwa penilaian kinerja berpengaruh positif dan sigifikan terhadap prestasi kerja. Penilaian kinerja merupakan salah satu aspek yang mampu mendorong pegawai untuk lebih kreatif dan inovatif berdasarkan kemampuan atau kecakapan pegawai dalam setiap pekerjaan yang mereka lakukan secara tepat waktu guna mendorong peningkatan prestasi kerja. Penelitian tersebut mendukung teori dari Malayu Hasibuan (2008:94) yang menyebutkan bahwa pestasi kerja adalah suatu hasil kerja yang dicapai seseorang dalam melaksanakan tugastugas yang dibebankan kepada yang didasarkan kecakapan, pengalaman dan kesungguhan serta waktu. Penilain kinerja basis e-kinerja merupakan terobosan baru pemerintah Kabupaten Banyuwangi untuk mendorong pegawai agar lebih inovatif dalam pekerjaan mereka. Sehingga dengan terciptanya inovasi yang mampu dikembangkan dalam bidang pelayanan publik pada yang berguna untuk melayani masyarakat secara luas serta mampu meningkatkan prestasi kerja pegawai Dinas Kependudukan dan Pencatatan Sipil Kabupaten Banyuwangi.

\section{Pengaruh Penilaian Kinerja Berbasis E-Kinerja Terhadap Kepuasan Kerja}

Berdasarkah hasil penelitian menunjukkan bahwa penilaian kinerja berbasis e-kinerja pada Dinas Kependudukan dan Pencatatan Sipil Kabupaten Banyuwangi memiliki pengaruh terhadap kepuasan kerja pegawai dengan hasil sebesar 0.626 atau $62.6 \%$. Nilai signifikansi pada penilaian kinerja berbasis e-kinerja sebesar 0.002, nilai ini lebih kecil dari nilai signifikansi yang telah ditetapkan sebesar 5\% (0.05). Hal tersebut mendefinisikan bahwa penilaian kinerja berbasis ekinerja dapat meningkatkan kepuasan kerja pegawai serta menunjukkan bahwa terdapat pengaruh positif dan signifikan. Penilaian kinerja berbasis e-kinerja diketahui bahwa 37 responden banyak yang memberi skor setuju terhadap indikator keberhasilan pelaksanaan tugas sebanyak 31 responden. Indikator kepuasan terhadap gaji memberikan jawaban sangat setuju sebesar 16 orang dalam hal ini kepuasan kerja dominan oleh indikator keberhasilan pelaksanaan tugas yang mampu dicapai oleh setiap pegawai Dinas Kependudukan dan Pencatatan Sipil Kabupaten Banyuwangi.

Berdasarkan pernyataan yang diberikan oleh responden terdapat 3 responden yang menyatakan tidak setuju, dianataranya pada indikator pengembangan potensi individu sebanyak 2 orang serta pada indikator keberhasilan dalam pelaksanaan tugas sebanyak 1 orang. Meskipun dari kedua indikator tersebut responden cenderung lebih banyak menjawab setuju, akan tetapi masih terdapat responden yang menjawab tidak setuju. Hasil pernyataan tersebut menunjukkan bahwa pada pegawai Dispendukcapil Kabupaten Banyuwangi masih ada pegawai yang tidak bisa mengembangkan potensi yang mereka miliki serta ketidak mampuan pegawai dalam melaksanakan tugas yang mereka kerjakan. Hasil wawancara diketahui bahwa dari pekerjaan yang mereka tempati tidak sesuai dengan potensi yang dimiliki, selain itu pekrjaan yang cenderung tetap mengakibatkan pegawai merasa kesulitan dalam mengembangkan potensi mereka. Beban kerja yang lebih berat serta target kerja yang harus diselesaikan, mengakibatkan pegawai tidak mampu melaksanakan tugas yang menjadi tanggung jawab dari setiap pegawai..

Pekerjaan yang sesuai dengan kemampuan pegawai didukung dengan kondisi kerja yang baik mampu meningkatkan kenyamanan dalam melakukan pekerjaan, sehingga hal tersebut mampu meningkat kepuasan bagi pegawai Dinas Kependudukan dan Pencatatan Sipil Kabupaten Banyuwangi. Hubungan kerja yang baik sangat penting untuk dibangun 
dalam organisasi guna untuk mendapatkan pengakuan terhadap hasil kerja oleh atasan dalam mendorong kesempatan untuk mendapatkan kesempatan promosi jabatan berdasarkan kinerja pegawai.

Hal ini, sesuai dengan hasil penelitian Arif Dwipayana et al. (2015) menyatakan bahwa sistem penilaian kinerja berpengaruh positif dan signifikan terhadap kepuasan kerja. Penerapan sisitem penilaian kinerja yang baik mampu meningkatkan kepuasan kerja pegawai. Adanya perubahan pada sisitem penilain kinerja menjadi elektronik kinerja memberikan mampu memberikan kepuasan terhadap pegawai dengan pemberian penilaian secara adil sesuai dengan kemampuan yang menjadi pekerjaan para pegawai. Teori ini juga didukung dari hasil penelitian terdahulu yang dilakukan oleh Teuku Syahputra (2016) menunjukkan bahwa penerapan e-kinerja pada pegawai cenderung menyulitkan, karena data harus dilakukan dengan media online, sehingga dengan diterapkannya pelatihan penggunaan e-kinerja mampu meningkatkan kepuasan kerja yang didapat oleh pengguna ekinerja itu sendiri. Pengalihan penilaian kinerja dari manual menjadi basis online cenderung lebih transparan dan adil, sehingga dari hal tersebut mampu meningkatkan kepuasan pegawai.

\section{Pengaruh Kepuasan Kerja Terhadap Prestasi Kerja}

Berdasarkan hasil analisis yang dilakukan dapat diketahui bahwa kepuasan kerja memiliki pengaruh terhadap prestasi kerja pegawai Dinas Kependudukan dan Pencatatan Sipil Kabupaten Banyuwangi sebesar 0.368 atau 36.8\% dengan tingkat signifikansi sebesar 0.000 . Nilai signifikansi yang diperoleh lebih kecil dari tingkat signifikansi yang telah ditentukan yakni sebesar $0.05 \quad(5 \%)$. Dari hasil tersebut menunjukkan bahwa kepuasan kerja memiliki pengaruh positif dan signifikan terhadap prestasi kerja pegawai. Pada variabel kepuasan kerja, diketahui dari 37 responden banyak yang memberi skor setuju sebanyak 31 orang atau $83.78 \%$ pada indikator keberhasilan pelaksanaan tugas. Dengan demikian diketahui bahwa keberhasilan pegawai dalam melaksanakan tugas yang diberikan oleh organisasi mampu meningkatkan kepuasan kerja yang didpat oleh pegawai Dinas Kependudukan dan Pencatatan Sipil Kabupaten Banyuwangi.

Hasil pemaparan tersebut mendukung penelitian yang dilakukan oleh Edy Suryanto (2015) yang menyatakan bahwa kepuasan kerja memiliki pengaruh positif dan signifikan terhadap prestasi kerja. Artinya, kepuaan kerja yang tinggi mampu meningkatkan prestasi kerja pegawai, sebaliknya apabila kepuasan kerja pegawai menurun hal tersebut dapat mengurangi hasil kinerja pegawai yang akan berdapak pada penurunan prestasi kerja. Hal ini mendukung pernyataan Hani (2014:193) yang menyatakan bahwa kepuasan kerja (job satisfaction) adalah keadaan emosional yang menyenangkan atau tidak menyenangkan dengan para karyawan memandang pekerjaan mereka. Kepuasan kerja merupakan aspek terpenting yang perlu diperhatikan dalam organisasi, apabila kepuasan kerja pegawai dapat ditingkatkan secara langsung hal tersebut mampu mempengaruhi prestasi kerja yang diperoleh pegawai Dinas Kependudukan dan Pencatatan Sipil Kabupaten Banyuwangi.

Apabila kepuasan kerja yang dirasakan oleh pegawai Dinas Kependudukan dan Pencatatan Sipil meningkat maka, hal tersebut mampu memberikan dampak yang baik terhadap kinerja yang dilakukan. Kepuasan kerja yang tinggi mampu memicu prestasi kerja yang lebih baik. Prestasi kerja dapat mendorong tercapainya keberhasilan organisasi dalam mengayomi serta memberi kesejahteraan kepada para pegawai. Keseluruahan indikator prestasi kerja mampu memberikan pegaruh yang baik kepada setiap pegawai dalam hal kemampuan untuk melakukan kerja sama baik didalam maupun diluar organisasi untuk menjalin kerja sama. Pengembangan kualitas dan kuantitas kerja pada pegawai perlu ditingkatkan untuk memperbaiki mutu kinerja pegawai Dispendukcapil Kabupaten banyuwangi. Tanggung jawab yang diberikan kepada pegawai bertujuan untuk mengukur kemampuan inisiatif kerja yang mampu dilakukan tanpa harus menunggu perintah dari atasan. Dengan dukungan kinerja yang baik dari pegawai Dinas Kependudukan dan Pencatatan Sipil Kabupaten Banyuwangi, serta kepuasan yang diperoleh sudah tercapai maka prestasi kerja akan meningkat.

\section{Pengaruh Penilaian Kinerja Berbasis E-Kinerja Terhadap Prestasi Kerja Melalui Kepuasan Kerja}

Berdasarkan hasil penelitian yang telah dilakukan menunjukkan pengaruh langsung pengaruh langsung penilaian kinerja berbasis e-kinerja terhadap kepuasan kerja pegawai sebesar 0.626 atau $62.6 \%$, sedangkan kepuasan kepuasan kerja memiliki pengaruh langsung terhadap prestasi kerja sebesar sebesar 0.368 atau $36.8 \%$. Pengaruh tidak langsung penilaian kinerja berbasis e-kinerja terhadap prestasi kerja pegawai melalui kepuasan kerja sebesar 0.23 atau 23\%. Berdasarkan hal tersebut, dapat diketahui pengaruh langsung penilaian kinerja dan kepuasan kerja memiliki pengaruh lebih besar yakni $62.6 \%$ dan $36.8 \%$ dibandingkan pengaruh tidak langsung yakni sebebsar $23 \%$.

Hal ini, mendukung dari penelitian Ratih Maria (2006) yang menyatakan bahwa efektivitas dari sistem penilaian kinerja memiliki pengaruh positif dan signifikan terhadap kepuasan kerja pegawai. Hasil tersebut mendukung teori Mondy (2008:257) penilaian kinerja merupakan merupakan faktor penting untuk mendukung tercapainya tujuan kinerja dengan menggunkan alat untuk mempengaruhi kinerja individu atau kelompok. Alat yang digunakan untuk mengukur kinerja tersebut dengan diterapkannya penilaian kinerja dengan basis elektronik kinerja yang diharapkan mampu meningkatkan kepuasan kerja serta prestasi kerja pegawai untuk membantu tercapainya tujuan organisasi.

Penerapan sistem penilaian kinerja berbasis e-kinerja terhadap prestasi kerja pegawai melalui kepuasan kerja pegawai Dispendukcapil Kabupaten Banyuwangi dilihat dari hasil analisis menunjukkan bahwa, penerapan sistem penilaian kinerja berbasis e-kinerja dan kepuasan dapat meningkatkan prestasi kerja pegawai. Hal ini timbul karena adanya persepsi yang baik tentang penetapan standar penilaian yang tersusun dengan baik dalam organisasi untuk menilai kinerja pegawai. Dari hasil wawancara pada Dinas Kependudukan dan Pencatatan Sipil terdapat masalah dimana terdapat pegawai yang memiliki kinerja kurang baik, sehingga pemberian umpan balik yang diberikan oleh penilai perlu dilakukan kepada pegawai yang memiliki kinerja buruk, maupun pegawai yang memiliki kinerja baik. Penerapan tersebut dilakukan dengan tujuan untuk melihat seberapa jauh inisiatif pegawai untuk melakukan pekerjaan 
yang lebih produktif tanpa menunggun perintah atasan guna meningkatkan prestasi kerja mereka. Penetapan sistem penilaian kinerja berbasis e-kinerja memberi kesempatan yang sama kepada setiap pegawai Dinas Kependudukan dan Pencatatan Sipil untuk berkompetisi secara adil untuk mendapatkan hasil prestasi yang memuaskan. Apabila pegawai mampu bekerja secara maksimal maka pegawai tersebut akan mendapatkan tunjangan lebih dari dari hasil kerja sebelumnya, dengan tujuan untuk meningkatkan kepuasan kerja yang diperoleh.

\section{Simpulan}

Penilaian kinerja berbasis e-kinerja berpengaruh positif dan signifikan terhadap kapuasan kerja pegawai Dinas Kependudukan dan Pencatatan Sipil Kabupaten Banyuwangi. Peniaian Kinerja berbasis e-kinerja berpengaruh positif dan sinifikan terhadap prestasi kerja pegawai Dinas Kependudukan dan Pencatatan Sipil Kabupaten Banyuwangi. Kepuasan Kerja memiliki pengaruh positif dan signifikan terhadap Prestasi kerja pegawai Dinas Kependudukan dan Pencatatan Sipil Kabupaten Banyuwangi.

\section{Referensi}

Arif Dwipayana, et al. 2015. Penerapan Sistem Penilaian Kinerja: Dampaknya Terhadap Kepuasan Kerja Dan Stress Kerja Karyawan. Bali: E-jurnal Ekonomi dan Bisnis Universitas Udayana, ISSN : 2337-3067.

Cindi Ismi. 2015. Pengaruh penilaian Kinerja Terhadap Kepuasan Kerja Dan Prestasi Kerja (Studi pada Karyawan PT.Telekomunikasi Indonesia, Tbk Wilayah Malang). Skripsi. Malang: Universitas Brawijaya.

Edy Suryanto. 2015. Pengaruh Kepuasan Kerja Dan Disiplin Kerja Terhadap Prestasi Kerja Karyawan C.V. JM Jaya Motor Semarang. Skripsi. Semarang: Universitas Pandanaran Semarang.

Elektronik Kinerja. Http://kinerja.banyuwangikab.go.id/ [diakses pada 28 Februaru 2017]

Hani T. Handoko. 2014. Manajemen Personalia dan Sumber Daya Manusia. Yogyakarta: BPFE-Yogyakarta.

JJIP Jawa Timur. Lahir Procot, Pulang Bawa Akta (LPPBA) di Banyuwangi. Http://jipp.jatimprov.go.id/?page=database_detail\&id=1 [diakses pada 01 Maret 2017].

Malayu Hasibuan. 2008. Manajemen Sumber Daya Manusia. Jakarta : Penerbit Bumi Aksara.

Mondy, Wayne. 2008. Manajemen Sumber Daya Manusia, jilid 1. ed-10. Jakarta: Erlangga.

Ratih Maria. 2006. Penilaian Kinerja Terhadap Motivasi Kerja, Kepuasan Kerja Dan Kinerja Karyawan PT Coats Rejo Indonesia. Skripsi. Bogor: Institut Pertanian Bogor.

Susilo Martoyo. 2006. Manajemen Sumber Daya Manusia. Yogyakarta: BPFE.

Teuku Syahputra. 2016. Kapabilitas Personal Dan Pelatihan E-Kinerja Terhadap Kepuasan Pengguna Sistem E-Kinerja Pada Satuan Kerja Perangkat Daerah Dinas Pemerintah Di Kota Banda Aceh. E-journal Akuntansi Universitas Syiah Kuala, Vol 2 No. 1. 